\title{
Analysis of the Russian Experience in the Implementation of Regional Financial Regulation
}

\author{
Badylevich R.V. \\ Luzin Institute for Economic Studies — Subdivision of the Federal Research Centre "Kola Science Centre of the Russian \\ Academy of Sciences" (IES KSC RAS) \\ Apatity, Russia \\ ramapatit@rambler.ru
}

\begin{abstract}
The article analyzes the implementation of regional financial regulation in Russia at the present stage of development. The urgency of studying the issues of financial regulation of territorial development in Russia is substantiated and the content of this element of state economic policy is given. The classification of key instruments of state financial regulation according to the specifics of their application is considered. The paper highlights general instruments that apply to all regions (the system of interbudgetary transfers and taxes regulated by regional authorities), and special tools used for the development of specific territories (program-targeted instruments, special legal statuses of territories and the creation of specialized financial institutions). The efficiency of using these tools and the degree of their impact on the economic systems of the constituent entities of the Russian Federation and their clusters (in particular, the Far Eastern Federal District, the North Caucasian Federal District, the Republic of Crimea and the city of Sevastopol, the Arctic zone of the Russian Federation, the Kaliningrad region) are evaluated. Special attention is paid to the possibilities of using each group of financial instruments to achieve the strategic priorities for the development of individual territories. It is concluded that in the conditions of our country, the most effective instrument of territorial development is currently state and federal development programs.
\end{abstract}

Keywords-regional financial regulation, interbudgetary transfers, regional taxes, targeted program instruments, special statuses of territories, financial development institutions

\section{INTRODUCTION}

Russia is the largest country in the world in terms of territory, its area is more than 17 million $\mathrm{km} 2$. According to the principle of state structure, the Russian Federation belongs to federal states and consists of 85 equal subjects. Such large territories and a large number of diverse regions, which are characterized by significant differences in population size, in the provision of natural resources, in the development of infrastructure, determine the objective need to find ways to implement effective regional financial regulation, whose task is not only to provide a sufficient financial base to ensure sustainable development of each constituent entity of the Russian Federation, but also creating conditions for reducing the regional asymmetry of development.
As the practice of implementing regional regulation shows, this element of the state's economic policy is the most important tool for supporting individual territories, for which the possibilities of building and realizing their own financial potential are limited. In addition, the targeted use of regulatory instruments allows solving the priority tasks of state policy in relation to strategically important territories of the country, for which the creation of conditions for attracting a sufficient financial base and the formation of the necessary investment resources for the implementation of large-scale projects is the basis for development.

The study and analysis of domestic experience of the most effective application of the instruments of regional financial regulation makes it possible to formulate recommendations for its further spread to other regions and territories.

\section{RESEARCH RESULTS}

Considerable attention is paid to the implementation of state financial regulation of territorial development (regional financial regulation) in the scientific literature. The foundations of this direction of research were formed in the works of such well-known Russian researchers as L.L. Igonina [1], A.G. Khachaturian [2], M.Yu. Molchanova, E.V. Petrova [3], E.B. Dyakova [4], L.S. Guryanova, T.S. Klebanov, V.S. Gvozditsky $[5,6]$ and many others. The study of the leading authors' approaches to the content and implementation of state financial regulation of territorial development makes it possible to define this element of economic policy as an activity of the state aimed at using financial instruments in order to eliminate disproportions in the development of individual territories, achieve the target parameters of socio-economic indicators of the functioning of the constituent entities of the Russian Federation and ensure the achievement of priority development goals of individual regions and their clusters.

At present, all instruments of state financial regulation of territorial development can be divided into two groups according to their specific application: general and special financial instruments (Fig. 1).

The key difference between these groups of financial instruments is that common instruments apply to all regions to 
the same extent. Special tools are implemented by the federal authorities in relation to specific territories.

At present, the system of interbudgetary transfers is a significant instrument of regional financial development. It includes such instruments as grants, subsidies, subventions and other inter-budgetary transfers to the budgets of the RF subjects. Some of these instruments are aimed at creating financial conditions for the implementation of the functions of regional authorities (subsidies, subventions), others at leveling the budgetary provision of regions (subsidies).

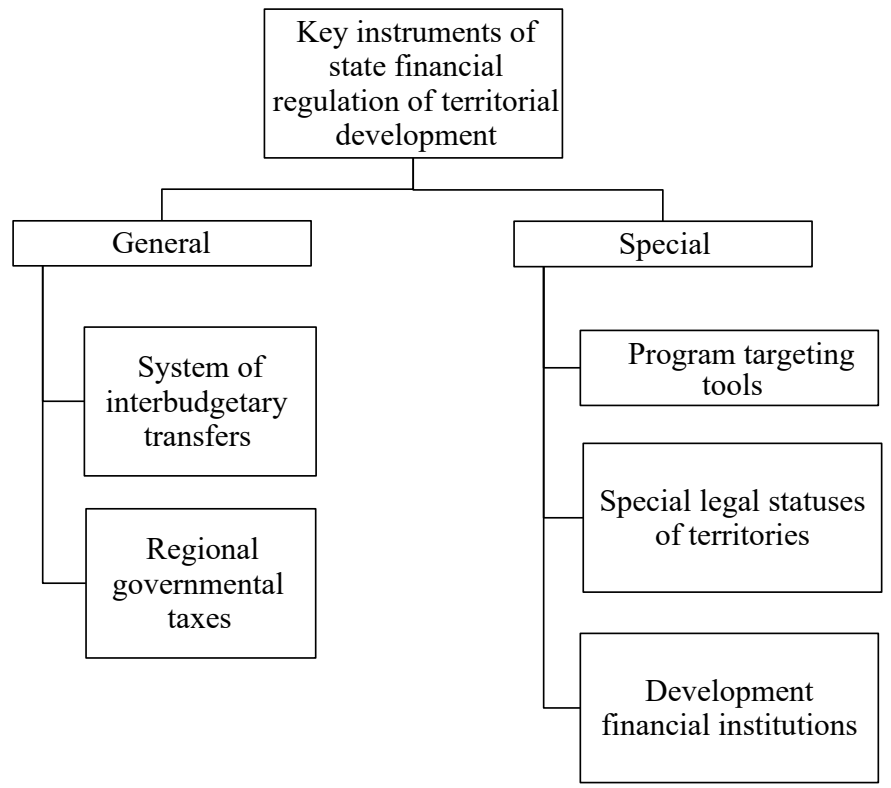

Fig. 1. Classification of key instruments of state financial regulation of territorial development by specific application.

Currently, a calculation method is used based on the number of resident population and the indices of tax potential and budget expenditures for each constituent entity of the Russian Federation to determine the amount of subsidies allocated to the region within the framework of the budgetary provision leveling system. In 2020, among 85 subjects of the Russian Federation, 72 subjects were subsidized (the largest amount of subsidies was received by the Republic of Dagestan, the Republic of Sakha (Yakutia), Kamchatka Territory), and only 13 regions did not receive subsidies. In Russia as a whole, the share of gratuitous transfers in the structure of incomes of the consolidated budgets of the constituent entities of the Russian Federation in 2019 exceeded 18\%. This situation indicates a weak filling of regional budgets and a clear lack of their own financial base. The reason for this is the policy of the federal authorities in recent decades, aimed at centralizing financial flows, while expanding the expenditure obligations of regional authorities; creating opportunities for the redistribution of tax payments by large companies operating in the field of extraction and processing of natural resources in the regions in favor of the federal budget; crisis phenomena in the economy associated with falling prices on commodity markets, the introduction of financial sanctions against our country. In 2020, additional financial pressure on regional budgets is exerted by the consequences of the novel coronavirus pandemic, which has led to the need for a significant increase in funding for regional health care, as well as a decrease in revenue due to a decrease in business activity and the shutdown of entire sectors of the economy.

Another common instrument of government financial regulation is the tax mechanism. There are three levels in the structure of taxes in Russia: federal, regional and local taxes. Currently, regional and local governments have the ability to set rates for regional and local taxes. Due to the fact that in the structure of tax revenues of the consolidated budgets of the constituent entities of the Russian Federation at the moment a significant share (about $80 \%$ of the total volume of tax revenues) falls on deductions from three federal taxes (corporate income tax, personal income tax and excise taxes), the possibilities for the authorities to significantly influence the filling of regional budgets with the help of tax instruments are very limited. The range of rates of regional and local taxes established in the Tax Code of the Russian Federation further reduces the importance of regulation based on tax instruments. Thus, in the system of fiscal policy at present, the balance in the use of instruments for regulating regional development is significantly shifted towards interbudgetary transfers. At the same time, foreign experience shows that in the practice of regional financial regulation, both budgetary instruments (for example, the experience of Finland [7]) and tax policy differentiated in a territorial context (in particular, the experience of the USA [8], Norway [9]) can prevail.

In Russia, target-oriented tools are actively used for territorial development. The program-targeted method of development is actively used in many countries that are similar in territorial structure and significant differentiation in the development of individual regions, for example, in Canada [10]. In 2020, in Russia, in total, there were about 40 state target programs and 20 federal target programs, some of which are part of national projects or state programs. Five out of the general list of state programs are currently aimed at the development of specific territories. These include state programs: "Socio-economic development of the Far Eastern Federal District", "Development of the North Caucasus Federal District", "Social and economic development of the Arctic zone of the Russian Federation", "Social and economic development of the Republic of Crimea and the city of Sevastopol", "Social -economic development of the Kaliningrad region". Among the independent federal target programs (not structurally included in the state programs), the program "Development of the Republic of Karelia" should be highlighted. The total amount of planned funding for the programs presented in 2020 is more than 250 billion rubles (Tab. 1).

The largest state programs aimed at the development of specific territories are programs for the socio-economic development of the Far Eastern Federal District, the Republic of Crimea and the city of Sevastopol and the Kaliningrad region.

In general, the program-targeted method is currently a priority tool for the development of individual regions and their clusters. But at the same time, the effectiveness of the implementation of the programs indicated in the table differs markedly.

One of the most effective programs in recent years is the program "Social and economic development of the Republic of Crimea and the city of Sevastopol". In 2014, the Republic of Crimea became part of the Russian Federation. At that time, significant efforts were required to integrate the region into the 
Russian Federation. These efforts were aimed at the sociocultural adaptation of the population of the republic to living in new conditions, the implementation of key areas of ensuring the security of the region, and the modernization of infrastructure. It was planned to allocate more than 900 billion rubles of budgetary resources for the implementation of these goals from 2014 to 2022.

TABLE I. General Characteristics OF STATE AND FEDERAL TARGET PROGRAMS IN 2020 FOR THE DEVELOPMENT OF SPECIFIC TERRITORIES [11]

\begin{tabular}{|c|l|c|c|}
\hline No & \multicolumn{1}{|c|}{ Program } & \multicolumn{1}{|c|}{$\begin{array}{c}\text { The volume of } \\
\text { budget } \\
\text { realization } \\
\text { financing in } \\
\text { 2020, billion } \\
\text { rubles. }\end{array}$} \\
\hline 1 & $\begin{array}{l}\text { Socio-economic development } \\
\text { of the Far Eastern Federal } \\
\text { District }\end{array}$ & $2014-2025$ & 54,1 \\
\hline 2 & $\begin{array}{l}\text { Development of the North } \\
\text { Caucasus Federal District until } \\
\text { 2025 }\end{array}$ & $2013-2025$ & 14,1 \\
\hline 3 & $\begin{array}{l}\text { Socio-economic development } \\
\text { of the Arctic zone of the } \\
\text { Russian Federation }\end{array}$ & $2015-2025$ & 0,2 \\
\hline 4 & $\begin{array}{l}\text { Socio-economic development } \\
\text { of the Republic of Crimea and } \\
\text { the city of Sevastopol }\end{array}$ & $2019-2022$ \\
\hline 5 & $\begin{array}{l}\text { Socio-economic development } \\
\text { of the Kaliningrad region }\end{array}$ & $2013-2025$ & 120,7 \\
\hline Independent federal targeted programs (not included in state programs) \\
\hline 6 & $\begin{array}{l}\text { Development of the Republic } \\
\text { of Karelia for the period up to } \\
\text { 2020 }\end{array}$ & $2016-2020$ & 4,1 \\
\hline
\end{tabular}

Despite the fact that the allocated funds were not always used in full, and some target indicators were never achieved, in a relatively short period of implementation of target programs for the development of the Republic of Crimea and the city of Sevastopol, several unique megaprojects were implemented, such as the construction of a railway and an automobile bridge across the Kerch Strait, reconstruction and modernization of the federal highway "Tavrida", as well as large-scale project to ensure the republic's energy independence from Ukraine. Much has been done in the development of the social sphere, transport infrastructure, tourism and hotel industry [12]. The key to the effectiveness of the target-oriented method in the development of the Republic of Crimea was the allocation of significant financial resources for the implementation of projects, as well as increased attention to the effectiveness of costs incurred by the higher authorities and the federal media.

The program for the socio-economic development of the Far Eastern Federal District became another significant and effective program in recent years. At the beginning of the XXI century, the Far Eastern Federal District came under the close attention of the President of the Russian Federation. The reason for this was the unfavorable dynamics of many socio-economic indicators of the district's regions, high rates of population outflow and growing interest in the region from the leading Asian countries and, above all, Japan. Considerable efforts have been made to develop this macro-region based on the programtargeted method. The first stage of development was implemented while preparing the infrastructure of the Far East for the APEC summit - 2012, the costs of which, according to the Accounting Chamber, amounted to about 680 billion rubles.
At the expense of these funds, a number of objects were built, including automobile infrastructure (a megaproject for the construction of a bridge to Russky Island was presented with special attention), hotels, port infrastructure, entertainment facilities.

Since 2014, a new stage in the socio-economic development of the Far Eastern Federal District has begun as part of the implementation of the state program, according to which it was decided to allocate more than 380 billion rubles to the region until 2025. With an unquestionably positive impact of the program on the level of economic development of the Far East and an increase in the investment attractiveness of the regions of the federal district, leading scientists have repeatedly expressed critical remarks about the implementation of the program, including those related to the lack of transparency of many costs, the overestimated cost of large investment projects, and insufficient attention to the development of social infrastructure [13].

Another territory, the development of which has received considerable attention in recent years, is the Kaliningrad region. The special geographical position of this region, on the one hand, requires significant efforts to preserve cultural, socioeconomic and political ties with the main territory of Russia, on the other hand, turns the Kaliningrad region into a unique military base and an instrument of pressure on other countries. The financial resources allocated to the region within the framework of the program-targeted approach are comparable to the volume of budget investments in the Far East and the Republic of Crimea. From 2013 to 2025, it is planned to allocate more than 660 billion rubles for the development of the Kaliningrad region (for example, only 65.7 billion rubles are planned to be allocated for the development of the Republic of Karelia within the framework of the federal target program "Development of the Republic of Karelia"). In the coming years, the main financial resources will be directed to support enterprises-residents of the special economic zone, the implementation of large transport projects (including the construction of a ferry for the Ust-Luga-Baltiysk railway ferry crossing, a bypass road around Kaliningrad, etc.), the development of tourism potential of Kaliningrad region. At the same time, the key problem in the implementation of this program is the low level of implementation of the program and the development of financial resources. In particular, in 2019 , the non-fulfillment of expenditures under the federal target program for the development of the Kaliningrad region for the period up to 2020 (a key element of the state program) amounted to $27 \%$ [14]. Similar problems are observed in 2020 , for example, as of September 1, 2020, the expenses of Rosmorrechflot and Rosmolodezh were fulfilled only by $2 \%$ and $9 \%$, respectively. Also, the implementation of the program is characterized by the failure to achieve many of the declared indicators (in 2019, such target values as the increase in the length of roads corresponding to regulatory requirements, electricity consumption and others were not achieved).

Since 2013, the state program "Development of the North Caucasus Federal District" has been implemented. At present, the total amount of pledged financing under this program is 175.7 billion rubles over 13 years. It should be noted that the program "Development of the North Caucasus Federal District" is one of the most criticized state programs of territorial development, in particular, the Accounts Chamber of the Russian Federation has repeatedly complained about 
ineffective spending of funds under the program, the program activities are not being implemented in full (for example, in 2017 - In 2018, out of 27 planned investment projects, only 9 were fully implemented), and the attracted extra-budgetary investments in recent years were 3-4 times less than those declared. The low efficiency of the program was also stated in the Government of the Russian Federation, and in June 2020 it was stated by Yuri Trutnev [15].

One of the most ineffective territorial development programs in recent years is the state program for the socioeconomic development of the Arctic zone of the Russian Federation. The total amount of planned financing under the program is about 7 billion rubles (of which 5.7 billion rubles were pledged for 2019). The program was repeatedly revised and edited, the last significant changes were made in February 2020, when a significant part of the activities from it was transferred to other departmental programs, and the amount of funding was reduced by 50 billion rubles. In addition, in 2019, the Accounts Chamber of the Russian Federation recognized this program as one of the most ineffective [16]. In the near future, with the approval in October 2020 of the new Strategy for the development of the Arctic zone of the Russian Federation and ensuring national security for the period until 2035, as well as the expansion of the tasks of the development institutions of the Far East to the Arctic zone, we should expect the reform of this program and an increase in the volume of its financing.

For the development of individual territories in Russia, the tool for creating territories with a special legal status is actively used. Currently, certain territories can be assigned the statuses of a special economic zone (SEZ) and a priority development area (PDA). Separately, two territories should be distinguished (in the Kaliningrad region and in the Magadan region), which have the status of a special economic zone, but at the same time their functioning is regulated by separate regulations and the conditions there differ markedly from those created within the framework of the Federal Law "On special economic zones in the Russian Federation" [17], as well as the free port of Vladivostok and the Skolkovo innovation center. In Russia, as of November 2020, there were 33 special economic zones of four types (15 industrial and production zones, 7 technology and innovation zones, 10 tourist and recreational zones and 1 port zone [18]). The SEZ status allows the introduction of significant benefits for business, such as reducing administrative barriers, tax and customs benefits, reducing rental payments, getting assistance in starting a business and supporting it. The key task of creating a SEZ is to attract additional investment to a certain territory. According to the Ministry of Economic Development of the Russian Federation, over 15 years of SEZ operation in Russia, the volume of attracted investments amounted to more than 440 billion rubles, and the number of new jobs created by their residents exceeded 38 thousand.

Simultaneously with the SEZ, as of November 2020, 87 PDAs functioned in single-industry towns, 3 PDAs in ZATOs and 21 PDAs in the Far East. During the work of the PDA according to the estimates of the Ministry of Economic Development, more than 27 thousand jobs were created and about 70 billion rubles of investments were attracted [19].

It is impossible to give an unambiguous assessment of the practice of creating territories with a special legal status in
Russia. On the one hand, the work of some of them shows high efficiency in creating jobs and attracting investments (for example, free economic zones "Alabuga" in Tatarstan, "Lipetsk", "Technopolis Moscow", "Dubna" and "St. Petersburg"), and the Ministry of Economic Development of the Russian Federation, based on the results of the assessment for 2019, assesses the efficiency of work in all SEZs (with the exception of tourist and recreational zones) at the level of 94.3\% [20], and on the other hand, according to the estimates of the Accounts Chamber of the Russian Federation, territories with a special status do not have a significant impact on the economy of individual regions and Russia as a whole [21], and some of them, having not achieved the stated goals, cease to exist (only in 2010-2017, 11 SEZs ceased to exist, on the creation of which about 4.5 billion rubles were given). The lack of consistency in the creation, lack of coordination in management (insufficient management efficiency on the part of management companies) and low utilization of territories with a special status should be noted as the reasons for the insufficient effectiveness of this tool for the development of territories.

The creation of specialized financial institutions (as a rule, they are created in the form of corporations or funds for the development of a certain territory) should be distinguished as a separate financial instrument for territorial development. Similar tools are actively used for regional development in foreign practice, in particular, in the United States for the development of Alaska, the Alaska Permanent Fund has been created [22], the European Regional Development Fund is functioning in Europe (ERDF) [23]. In Russia, such structures are currently quite common, but most of them are ineffective. This is primarily due to the limited financial resources they have. One of the few examples of the effective creation and functioning of such structures is the Far East Development Fund. The Fund was created as a subsidiary of the state development corporation VEB.RF (this allows the Fund to have a total assets of more than 80 billion rubles), and its activities are aimed at long-term financing of priority large investment projects on preferential terms in the regions of the Far East, and more recently in the Russian Arctic. The Fund participates in the implementation of large projects, including those planned under the state program for the development of the Far East. The total volume of projects implemented with the participation of the Fund today exceeds 500 billion rubles, making it an effective tool for the development of the Far Eastern Federal District.

\section{CONCLUSION}

The analysis showed that at present in Russia two groups of financial instruments are used to regulate regional development. The first group is the instruments of fiscal budgetary and tax policy, first of all, the system of interbudgetary transfers. At present, the system of budget equalization based on federal subsidies makes it possible to reduce regional asymmetry, but the amount of allocated funds is more aimed at meeting the current needs of the regions and is not able to significantly influence the development of the financial and production potential of the territories.

The second group of financial instruments (special instruments) is used for the targeted development of territories. As practice shows, the most effective tool among this group of levers is state and federal development programs. But at the 
same time, the prerequisites for the effective use of the target program tool are a sufficient amount of pledged and utilized financing, the presence of clear targets and a well-thought-out program of measures in the implementation of the program, the symbiosis of efforts on the part of both federal and regional authorities in the implementation of the program and the presence of an effective system control over the implementation of the program by federal control bodies and the public.

The most significant results in the development of individual territories can be achieved by combining the use of program-targeted instruments (state development programs), the formation of specialized financial institutions and the creation of territories with a special status.

\section{Acknowledgments}

The study was carried out within the framework of the RFBR grant 20-010-00776 "Improving state financial regulation of the development of the regions of the Arctic zone of the Russian Federation as the basis for ensuring the economic security of the Russian Arctic".

\section{References}

[1] L.L. Igonina, "Modern Trends in the Development of Regional Finance [Sovremennyye tendentsii razvitiya regional'nykh finansov]", Finance, 2018, vol. 11, pp. 20-27.

[2] A.G. Khachaturyan, "Financial Regulation Of Territorial Development In Russia [Finansovoye regulirovaniye territorial'nogo razvitiya v Rossii]", Dissertation for the degree of Doctor of Economics, Saratov State Social and Economic University, Saratov, 2008, 386 p.

[3] M.Yu. Molchanova, E.V. Petrova, "Fiscal Regulation Of Territorial Development [Byudzhetno-nalogovoye regulirovaniye territorial'nogo razvitiya]", Ministry of Education and Science of Russian Federation, Perm State National Research University, 2013, 229 p.

[4] E.B. Dyakova, "Theory And Methodology Of Budgetary Regulation Of Territorial Development [Teoriya i metodologiyabyudzhetnogo regulirovaniya territorial'nogo razvitiya]", Volgograd: Volgograd Scientific Publishing House, 2011, 144 p.

[5] L.S. Guryanova, T.S. Klebanova, and V.S. Gvozdytskiy, "Econometric Modelling Of The Financial Regulation Mechanism In Regional Development", Actual Problems of Economics, 2015, Vol. 173(11), pp. 408-421.

[6] R. Brumnik, T. Klebanova, L. Guryanova, S. Kavun, and O. Trydid, "Simulation Of Territorial Development Based On Fiscal Policy Tools", Mathematical Problems in Engineering, 2014, Vol. 2014, 843976, DOI: 10.1155/2014/843976.

[7] G. Nitti, "Regional Development Policy In Finland", Journal of Regional Policy, 1985, Vol. 5(2), pp. 261-286.

[8] J.E. Leightner, "Fiscal Stimulus For The Usa In The Current Financial Crisis: What Does 1930- 2008 Tell Us?", Applied Economics Letters, 2001, vol. 18(6), pp. 539-549.

[9] E. Angell, Y. Flo and G. Marit, "Rural and Regional Policy of Norway. Institutions, Development Features And Current Instruments", Rokkan Centre. Stein Rokkan Centre for Social Studies, Report, 5-2016, Retrieved from

https://www.regjeringen.no/contentassets/744de1ad6f0f4df09311c33edd0 1ae99/trykk_gront-hefte.pdf.

[10]N. Bradford and D.A. Wolfe, "Governing Regional Economic Development: Innovation Challenges And Policy Learning In Canada”,
Cambridge Journal of Regions, Economy and Society, Vol. 6(2), July 2013 pp 331-347. DOI: $10.1093 /$ cjres/rst006.

[11] Information about the current state programs of the Russian Federation [Informatsiya o deystvuyushchikh gosudarstvennykh programmakh RF]. Official website of the Government of the Russian Federation. Retrieved from: http://government.ru/rugovclassifier/section/2649/.

[12]A.O. Znamenshchikov, "Republic Of Crimea And Sevastopol: The Firs Results Of The Implementation Of State Programs In The Economic And Social Spheres [Respublika Krym i Sevastopol': pervyye itogi realizatsi gosudarstvennykh programm v ekonomicheskoy i sotsial'noy sferakh]", Management Consulting, 2019, vol. 10(130), pp. 100-109.

[13]A.G. Aganbegyan, "Development Of The Far East: A National Program In The Context Of National Projects [Razvitiye Dal'nego Vostoka: natsional'naya programma v kontekste natsional'nykh proyektov]", Spatial Economics, 2019, vol. 15(3), pp. 165-181.

[14]Conclusion of the Kaliningrad Region Control and Accounts Chamber on the report on the execution of the regional budget for 9 months of 2019 // Considered and approved at a meeting of the Board of the Kaliningrad Region Control and Accounts Chamber [Zaklyucheniye kontrol'noschetnoy palaty Kaliningradskoy oblasti na otchet ob ispolnenii oblastnogo byudzheta za 9 mesyatsev 2019 goda // Rassmotreno i odobreno na zasedanii kollegii kontrol'no- schetnoy palaty Kaliningradskoy oblasti] (Minutes No. 23 dated of 21.11.2019).

[15] Materials of the meeting on measures for the development of the North Caucasian Federal District. Official website of the Government of the Russian Federation [Materialy soveshchaniya o merakh po razvitiyu Severo-Kavkazskogo federal'nogo okruga. Ofitsial'nyy sayt Pravitel'stva RF]. Retrieved from: http://government.ru/news/39892/.

[16] Analysis of state programs for 2019. Official website of the Accounts Chamber of the Russian Federation [Analiz gosprogramm za 2019 god. Ofitsial'nyy sayt Schetnoy palaty RF]. Retrieved from: https://ach.gov.ru/audit/gosprog-2019.

[17]Federal Law of July 22, 2005 No. 116-FZ "On Special Economic Zones in the Russian Federation” [Federal'nyy zakon ot 22 iyulya 2005 g. № 116 FZ «Ob osobykh ekonomicheskikh zonakh v Rossiyskoy Federatsii»] (as amended on July 18, 2017), Collected Legislation of the Russian Federation, 25.07.2005, vol. 30 (Part II), Ar. 3127.

[18] Information about the SEZ in the Russian Federation. Official website of the Ministry of Economic Development of the Russian Federation [Svedeniya ob OEZ v RF. Ofitsial'nyy sayt Ministerstva ekonomicheskogo razvitiya $\quad \mathrm{RF}$ ]. Retrieved from: https://www.economy.gov.ru/material/directions/regionalnoe_razvitie/inst rumenty razvitiya territoriy/osobye ekonomicheskie zony/.

[19] Information about the PDA in the Russian Federation. Official website of the Ministry of Economic Development of the Russian Federation [Svedeniya ob TOR v RF. Ofitsial'nyy sayt Ministerstva ekonomicheskogo razvitiya $\quad \mathrm{RF}$. Retrieved from: https://www.economy.gov.ru/material/directions/regionalnoe_razvitie/inst rumenty razvitiya territoriy/tor/.

[20]Report of the Ministry of Economic Development of the Russian Federation on the results of the functioning of special economic zones for 2019 and for the period since the beginning of the functioning of special economic zones [Otchet Minekonomrazvitiya RF o rezul'tatakh funktsionirovaniya osobykh ekonomicheskikh zon za 2019 god i za period s nachala funktsionirovaniya osobykh ekonomicheskikh zon]. Retrieved from:

https://www.economy.gov.ru/material/file/f4433587b2be6ef9fbc3f9426d 8b7cab/\%D0\%BE\%D1\%82\%D1\%87\%D0\%B5\%D1\%82.pdf.

[21]Retrieved from: https://ach.gov.ru/checks/sp-ne-uvidela-proryvnogovliyaniya-preferentsialnykh-rezhimov-na-ekonomiku-rossii

[22]R.M. Feinberg and D. Kuehn, "Does a Guaranteed Basic Income Encourage Entrepreneurship? Evidence from Alaska", Review of Industrial Organization, Vol. 57(3), November 2020, pp. 607-626, DOI: 10.1007/s11151-020-09786-8.

[23] V. Vehkasalo, "Effectiveness of EU regional policy: Evidence from a natural experiment in Finland", Region, Vol. 5(3), 2 July 2018, pp 1-19, DOI: 10.18335/region.v5i1.195 